\title{
Chronic cerebral hypoperfusion induced synaptic proteome changes in the rat cerebral
} cortex

Katalin Völgyi ${ }^{1 *}$, Péter Gulyássy ${ }^{2 *}$, Mihail Ivilinov Todorov ${ }^{1,3}$, Gina Puska ${ }^{5}$, Kata Badics ${ }^{3}$, Dávid Hlatky ${ }^{4}$, Katalin Adrienna Kékesi ${ }^{2,6}$, Gabriella Nyitrai ${ }^{4}$, András Czurkó ${ }^{4}$, László Drahos $^{2 * *}$, Arpád Dobolyi ${ }^{1 * *}$

${ }^{1}$ MTA-ELTE NAP B Laboratory of Molecular and Systems Neurobiology, Institute of Biology, Hungarian Academy of Sciences and Eötvös Loránd University, Budapest, Hungary; ${ }^{2}$ MTA-TTK NAP B MS Neuroproteomics Research Group, Hungarian Academy of Sciences, Budapest, Hungary; ${ }^{3}$ Laboratory of Proteomics, Institute of Biology, Eötvös Loránd University, Budapest, Hungary; ${ }^{4}$ Preclinical Imaging and Biomarker Laboratory, Pharmacology and Drug Safety Research, Richter Gedeon Plc, Budapest, Hungary; ${ }^{5}$ Department of Anatomy, Cell and Developmental Biology, Eötvös Loránd University, Budapest, Hungary, ${ }^{6}$ Department of Physiology and Neurobiology, Eötvös Loránd University, Budapest, Hungary

* These authors contributed equally to this work.

** These authors share senior author responsibilities.

${ }^{*}$ Correspondence:

Katalin Völgyi

Laboratory of Molecular and Systems Neurobiology, Hungarian Academy of Sciences and Eötvös Loránd University,

Pázmány Péter sétány 1C, Budapest, H-1117, Hungary

Email: katvolgyi@gmail.com

Tel.: +36-1-372-2500/8773

Fax.: +36-1-218-1612

\begin{abstract}
Chronic cerebral hypoperfusion $(\mathrm{CCH})$ evokes mild cognitive impairment $(\mathrm{MCI})$ and contributes to the progression of vascular dementia and Alzheimer's disease (AD). How $\mathrm{CCH}$
\end{abstract}


induces these neurodegenerative processes that may spread along the synaptic network and whether they are detectable at the synaptic proteome level of the cerebral cortex remains to be established.

In the present study, we report the synaptic protein changes in the cerebral cortex after stepwise bilateral common carotid artery occlusion (BCCAO) induced $\mathrm{CCH}$ in the rat. The occlusions were confirmed with Magnetic Resonance Angiography 5 weeks after the surgery. Synaptosome fractions were prepared using sucrose gradient centrifugation from cerebral cortex dissected 7 weeks after the occlusion. The synaptic protein differences between the sham operated and $\mathrm{CCH}$ groups were analysed with label free nanoUHPLC-MS/MS.

We identified 46 proteins showing altered abundance due to $\mathrm{CCH}$. In particular, synaptic protein and lipid metabolism, as well as GABA shunt related proteins showed increased while neurotransmission and synaptic assembly related proteins showed decreased protein level changes in $\mathrm{CCH}$ rats. Protein network analysis of $\mathrm{CCH}$ induced protein alterations suggested the importance of increased synaptic apolipoprotein E (APOE) level as a consequence of $\mathrm{CCH}$. Therefore, the change in APOE level was confirmed with Western blotting. The identified synaptic protein changes would precede the onset of dementia-like symptoms in the $\mathrm{CCH}$ model suggesting their importance in the development of vascular dementia.

Keywords:, Chronic cerebral hypoperfusion, vascular dementia, Alzheimer's disease, synaptic proteome, label free LC-MS/MS, GABAergic synapse, apolipoprotein E

Abbreviations: $\mathrm{AD}=$ Alzheimer's disease, $\mathrm{APOE}=$ apolipoprotein $\mathrm{E}, \mathrm{BCCAO}=$ Bilateral common carotid artery occlusion, $\mathrm{CCH}=$ chronic cerebral hypoperfusion

Acknowledgements: This study was supported by Gedeon Richter Plc, the Hungarian National Research, Development and Innovation Office (KMOP-1.1.5-08-2009-0001, 
KTIA_NAP_13-1-2013-0001, KTIA_NAP_B_13-2-2014-0004 and KTIA_NAP_13-2-20150003 programs). The founders had no role in study design; in the collection, analysis and interpretation of data; in writing of the manuscript; and in the decision to submit the article for publication. We would like to thank Dr. Gábor Juhász for helpful discussions on the research plan.

\section{Introduction}

Chronic cerebral hypoperfusion $(\mathrm{CCH})$ is relatively common in the elderly and it is a major contributor to cerebrovascular dementia (Cankurtaran et al., 2008, Valerio Romanini et al., 2013) and also an important risk factor for Alzheimer's disease (AD) (Sato and Morishita, 2013). However, the molecular background how $\mathrm{CCH}$ causes cognitive impairment and how it contributes to Alzheimer's pathogenesis is poorly understood, even though a deeper understanding of the molecular process would be essential for developing new therapeutic strategies to prevent the progression of $\mathrm{CCH}$ towards $\mathrm{AD}$.

$\mathrm{CCH}$ can be detected in mild cognitive impairment prior to dementia using different imaging techniques (Borroni et al., 2006). CCH causes capillary degeneration, which reduces the diffusion of nutrition and oxygen supply to brain cells resulting in the degeneration of the nerve tissue. The onset of $\mathrm{CCH}$ is in the associative cortical areas, then it spreads throughout the brain via the neuronal network, affecting large parietal and temporal cortical areas (Zadori et al., 2007). Synapse loss is an early feature of AD which correlates with the severity of dementia (Shankar and Walsh, 2009).

Bilateral common carotid artery occlusion (BCCAO) induced $\mathrm{CCH}$ is a widely used model of vascular dementia (Farkas et al., 2007, Jing et al., 2015). For better survival rate and to avoid the acute ischemic stroke, we used a $\mathrm{CCH}$ model where $\mathrm{BCCAO}$ was induced with one-week interval between occlusions of the left and right common carotid arteries (Cechetti 
et al., 2010), which leads to a more gradual development of $\mathrm{CCH}$ in the brain (Jing et al., 2015). The rat is a frequently used species of this model due to its good recovery rate from surgery, the good reproducibility, and because the complete circle of Willis allows permanent carotid occlusion during a period of reduced blood flow after the onset of BCCAO. This animal model shows learning and memory impairments resembling those found in AD and vascular dementia, accompanied by neuronal degeneration, long-lasting white matter lesion, microglial activation, astrocytosis and microvascular abnormalities (de la Torre et al., 2003, Farkas et al., 2007). White matter damage is detectable with diffusion tensor imaging (DTI) at the early stages of brain injury following $\mathrm{CCH}$ (Wang et al., 2015). In addition, cerebral hypoperfusion accelerates cerebral amyloid angiopathy (Okamoto et al., 2012), enhances tau hyperphosphorylation, upregulates $\beta$-amyloid precursor protein cleavage enzyme 1 (BACE1) and $\beta$-amyloid level in the brain (Zhiyou et al., 2009), the main neuropathological hallmarks of AD.

Although the underlying pathophysiological mechanisms and their consequences have been widely studied in the $\mathrm{CCH}$ model, unbiased proteomic studies are scarce and the molecular changes in $\mathrm{CCH}$-affected brain are not well understood. Because $\mathrm{CCH}$ induced neurodegeneration spreads along the neuronal networks, the aim of the present study was to describe the effect of $\mathrm{CCH}$ on synaptic proteome of the rat cerebral cortex focusing on its possible role in the progression of AD.

\section{Methods}

\section{Animals}

The care and experimentation of all animals conformed to the Hungarian Act of Animal Care and Experimentation (1998, XXVIII) and to the guidelines of the European Communities Council Directive, 86/609/EEC as well as with local regulations for the care and 
use of animals for research. Rats were kept under standard laboratory conditions (12-hour light/dark cycle, lights on at 08.00 a.m. and off at 08.00 p.m.) with free access to food and water. Three months old male Harlan Wistar rats (weights 310-390 g at the beginning of the experiments) were subjected to stepwise complete bilateral occlusion of the common carotid arteries $(n=6)$. Sham operated rats without artery occlusion served as control group $(n=6)$. For better survival rate and to avoid the ischemic lesions of the brain, the two common arteries were occluded with one week delay (stepwise BCCAO) and the sham operated animals were also operated with this schedule.

\section{Stepwise occlusion of common carotid arteries}

Rats were anesthetized with isoflurane (1.5-2\% in air); and a ventral midline incision was made on the neck. Common carotid arteries were exposed and gently separated from the vagus nerve and the left carotid artery was occluded in the first step by three ligatures (2-0). One week later a new incision was made and the right carotid was occluded as well in the second step. The sham operated animals were also operated with this schedule, the same thread (2-0) was placed around the vessels without ligatures. After the procedure, rats were put back to their home cages and allowed to recover.

\section{Magnetic Resonance Angiography}

The occlusions were confirmed with Magnetic Resonance Angiography (MRA). 5 weeks after the second occlusion anaesthetized animals (isoflurane in air 1-1.5\%) were scanned in a 9.4 T MRI system (Varian, Medical Systems Inc., Palo Alto, CA) with a free bore of $210 \mathrm{~mm}$, containing a $120 \mathrm{~mm}$ inner size gradient coil. 3D time-of-flight (TOF) angiography (3D gradient echo) was performed with $\mathrm{TR} / \mathrm{TE}=30 / 2.8 \mathrm{msec}$, resolution $=0.42$ x $0.42 \times 0.46 \mathrm{~mm}$. 


\section{Dissection of cerebral cortical samples}

The Wistar rats from both groups $(n=6-6)$ were anesthetized with isoflurane $(1-1.5 \%$ in air) then decapitated and the brains were removed rapidly. The brains were washed in artificial cerebral spinal fluid (ACSF), the cerebral cortices were dissected and the tissue samples were immediately frozen on dry ice and stored at $-80{ }^{\circ} \mathrm{C}$ until further studies.

\section{Isolation of synaptosomes from rat cerebral cortical samples}

Synaptosomes were prepared by the method of Hahn et al. with minor modifications (Hahn et al., 2009). Briefly, the cerebral cortical tissue was homogenized using a Dounce type glass homogenizer (Small Clearance, Kontes Glass Co.) with 40 strokes in $1 \mathrm{ml}$ of homogenization buffer (320 mM sucrose, $0.1 \mathrm{mM} \mathrm{CaCl}_{2}, 1 \mathrm{mM} \mathrm{MgCl}$ ) supplemented with protease and phosphatase inhibitor cocktails (Sigma-Aldrich, St.Louis, MO, USA). To avoid postmortem degradation all steps were performed on ice in a cold room. The homogenate was adjusted to $1.25 \mathrm{M}$ sucrose and $0.1 \mathrm{mM} \mathrm{CaCl}_{2}$ to a total volume of $5 \mathrm{ml}$ and was transferred to a centrifuge tube. $5 \mathrm{ml}$ of $1 \mathrm{M}$ sucrose solution was overlaid on it and centrifuged at 100000 $\times \mathrm{g}$ for 3 hours in an SW-40 rotor. The band at the interface was collected with a needle as the synaptosome fraction. To reduce the sucrose content of the fraction the sample was diluted with $5 \times 0.1 \mathrm{mM} \mathrm{CaCl}_{2}$ and centrifuged at $15000 \times \mathrm{g}$ for $20 \mathrm{~min}$. The pellet was precipitated with ice cold acetone overnight. On the next day the sample was spinned down, the acetone was removed and the pellet was allowed to dry.

\section{Electron microscopy validation of synaptosome samples}

For the electron microscopic validation, synaptosome fractions were fixed with $2 \%$ formaldehyde (freshly depolymerized from paraformaldehyde) and $0.5 \%$ glutaraldehyde in 
$0.1 \mathrm{M} \mathrm{Na}$-cacodylate for $30 \mathrm{~min}$ at room temperature. The samples were postfixed in $0.5 \%$ osmium tetroxide and $0.75 \%$ potassium hexacyano-ferrate for $45 \mathrm{~min}$, dehydrated and embedded in LR White resin according to the manufacturer's instructions. Ultrathin sections $(70 \mathrm{~nm})$ were examined in JEOL JEM 1011 electron microscope operating at $60 \mathrm{kV}$. Images were taken with an Olympus Morada 11-megapixel camera and iTEM software (Olympus).

\section{Processing of synaptosomes for proteome analysis}

The precipitated samples were taken up in lysis buffer (7 M urea, $2 \mathrm{M}$ thiourea, 20 $\mathrm{mM}$ Tris, $5 \mathrm{mM} \mathrm{Mg}(\mathrm{Ac})_{2}, 50 \mathrm{mM}$ DTT) and were sonicated on ice until completely dissolved. The concentration was determined using the 2D Quant Kit (GE Healthcare, Little Chalfont, UK). The proteins were digested using the filter aided sample preparation method published by Wisniewski et al. with minor modifications (Wisniewski et al., 2009). Briefly, $150 \mu \mathrm{g}$ of the sample was diluted to a volume of $200 \mu \mathrm{l}$ with urea buffer ( $8 \mathrm{M}$ urea, $100 \mathrm{mM}$ Tris-HCl $\mathrm{pH}$ 8.5) transferred to a Microcon YM-30 filter device (Merck, Germany) and spinned down at $14000 \times \mathrm{g}$ for $15 \mathrm{~min}$ at room temperature. Then $200 \mu \mathrm{l}$ urea buffer was added to the sample and spinned down again. To carbamidomethylate the proteins, $100 \mu 1$ of IAA solution (50 mM iodoacetamide, $8 \mathrm{M}$ urea, $100 \mathrm{mM}$ Tris- $\mathrm{HCl} \mathrm{pH} 8.5$ ) was pipetted onto the filter and mixed at $450 \mathrm{rpm}$ at room temperature for $3 \mathrm{~min}$ in a thermo-mixer. Then incubated for $45 \mathrm{~min}$ at RT in dark without mixing and the sample was centrifuged for $10 \mathrm{~min}$ at the end. $100 \mu 1$ of urea solution was added to the sample, spinned down for $15 \mathrm{~min}$, and this step was repeated twice. Later, $100 \mu \mathrm{l}$ of $50 \mathrm{mM} \mathrm{NH}_{4} \mathrm{HCO}_{3}$ was added and the sample was centrifuged for $10 \mathrm{~min}$, and this step was also repeated twice. The proteins were recovered from the filter by a reverse spin of $1500 \times \mathrm{g}$ for $3 \mathrm{~min}$ and $100 \mu \mathrm{l}$ of digestion solution $(0.1 \%$ RapiGest, $50 \mathrm{mM} \mathrm{NH} \mathrm{HCO}_{3}$ ) and trypsin (Sequencing grade modified, Promega, Madison, WI, USA) were added in a 1:50 ratio. The sample was digested overnight at $37{ }^{\circ} \mathrm{C}$. The 
following day the reaction was stopped by adding $4 \mu \mathrm{l}$ of formic acid and the sample was desalted on a Pierce C-18 spin column (Thermo Scientific, Sunnyvale, CA, USA) according to the instruction of the supplier and dried in a speed-vac.

\section{Protein identification by nanoUHPLC-MS/MS}

Liquid chromatography-mass spectrometry was performed using a Maxis II ETD QqTOF (Bruker Daltonics, Bremen, Germany) coupled to an Ultimate 3000 nanoRSLC system (Dionex, Sunnyvale, CA, USA) under the control of Hystar v.3.2 (Bruker Daltonics, Bremen, Germany). Samples were dissolved in $40 \mu \mathrm{l}$ of $2 \%$ Acetonitril and $0.1 \%$ formic acid in water, out of which $5 \mu 1$ were injected onto an Acclaim PepMap100 C-18 trap column (100 $\mu \mathrm{m}$ x $20 \mathrm{~mm}$, Thermo Scientific, Sunnyvale, CA, USA). Sample desalting and preconcentration were performed with $0.1 \%$ trifluoracetic acid for 8 min with a flow rate of 5 $\mu 1 /$ min. Peptides were separated on an ACQUITY UPLC M-Class Peptide BEH C18 column (130 ̊, $1.7 \mu \mathrm{m}, 75 \mu \mathrm{m} \times 250 \mathrm{~mm}$, Waters, Milford, MA, USA) at $48{ }^{\circ} \mathrm{C}$ using a flow rate of $300 \mathrm{nl} / \mathrm{min}$. HPLC solvents were as follows: solvent A consisted of $0.1 \%$ formic acid in water and solvent $\mathrm{B}$ consisted of $0.1 \%$ formic acid in acetonitrile. The gradient was as follows: $4 \% \mathrm{~B}$ from 0 to $11 \mathrm{~min}$, followed by a $120 \mathrm{~min}$ gradient to $50 \% \mathrm{~B}$, then the concentration of the solvent B was elevated to $90 \%$ in 1 min and kept there for $10 \mathrm{~min}$. After each sample a blank was ran to avoid carryover. Sample ionization was achieved in the positive electrospray ionization mode via a CaptiveSpray nanoBooster ion source. The capillary voltage was set to $1300 \mathrm{~V}$, the nanoBooster pressure was $0.2 \mathrm{Bar}$, the drying gas was heated to $150{ }^{\circ} \mathrm{C}$ and the flow rate was $31 / \mathrm{min}$. External mass calibration was done using the low concentration tuning mix from Agilent technologies via direct infusion. Internal mass calibration was performed via lock mass for each run using sodium formate. The ion transfer parameters were set as follows: prepulse storage $10 \mu \mathrm{s}$, collision transfer $10 \mu \mathrm{s}$, quadrupole 
ion energy 5 eV, Funnel 1 RF 400 Vpp, Multipole RF 400 Vpp. The collision RF was set to $1200 \mathrm{Vpp}$ and the ion transfer time was $120 \mu \mathrm{s}$. The MS spectra were recorded with a fix cycle time of $2.5 \mathrm{sec}$ over the mass range of $\mathrm{m} / \mathrm{z} 150-2200$ at $3 \mathrm{~Hz}$ with a minimal precursor mass of $322 \mathrm{~m} / \mathrm{z}$. The CID was performed at $16 \mathrm{~Hz}$ for abundant precursors and at $4 \mathrm{~Hz}$ for ones of low abundance. Singly charged peptides were excluded from the analysis, only multiple charged peptides were chosen for fragmentation. The collision energy for precursor signals was set automatically followed by the manufacturer's recommendations based on the isolation $\mathrm{m} / \mathrm{z}$, isolation mass range width and charge state of the ion. An active exclusion of 2 min after 1 spectrum was used except if the intensity of the precursor was elevated threefold. For protein content analysis, raw data were recalibrated using the Compass DataAnalysis software 4.3 (Bruker Daltonics, Bremen, Germany). The samples were matched with the Rattus norvegicus SwissProt database using the Mascot server v.2.5 (Matrix Science, London, UK). The parameters for the Mascot search were set as follows: trypsin as the enzyme, and maximum 2 missed cleavages were allowed. Cysteine carbamidomethylation and methionin oxidation were used as fixed and variable modifications, respectively. Precursor mass tolerance was set to $7 \mathrm{ppm}$, the MS/MS mass tolerance was $0.05 \mathrm{Da}$. Decoy database was generated by Mascot and the false discovery rate was less than $1 \%$ in each search result. Proteins with a minimum of two identified, unique peptides were accepted. Label free quantification was performed using MaxQuant software version 1.5.3.30. LC-MS/MS runs were aligned using the "match between runs" feature (match time window 0.8 min, alignment time window $15 \mathrm{~min}$ ). The following requirements were set: minimum peptide ratio count 2 and ,unique + razor” peptide for quantification. Only the peptides without modifications were taken into consideration in quantitative analysis.

\section{Functional clustering}


Significantly altered proteins were clustered on the basis of the UniProt (http://www.uniprot.org/) and GeneOntology (http://geneontology.org/) databases. The proteins showing increased or decreased expression levels were clustered separately in groups according to their most relevant cellular functions and roles in synaptic processes (Table 1 and 2).

\section{Bioinformatic analysis of significant protein changes}

The bioinformatic pathway analysis to uncover the linkage between $\mathrm{AD}$ and the $\mathrm{CCH}$ induced significantly altered cortical synaptic proteins was performed by Elsevier Pathway Studio Platform.

\section{Western blot}

Among the mass spectrometry identified $\mathrm{CCH}$ induced significant protein changes APOE was selected for WB validation as it is known to have a major role in Alzheimer's and cardiovascular diseases. For validation the same samples were used which were utilized in the mass spectrometry analysis. Proteins were separated with Tricine-SDS-polyacrylamide gel electrophoresis on $10 \%$ polyacrylamide gels and transferred to Hybond-LFP PVDF membranes (GE Healthcare). The membranes were blocked with $5 \%$ BSA in Tris-buffered saline containing $0.1 \%$ Tween 20 (TBS-T). The membranes were incubated overnight in rabbit anti-apolipoprotein E primary antibody (EPR19392) (Abcam, ab183597, 1:500 dilution) and mouse anti-synaptophysin (SY38) (monoclonal) primary antibody (Abcam, ab8049, 1:1500 dilution) dissolved in TBS-T. Subsequently, the membranes were washed for 4 x 5 min in TBS-T followed by the incubation with Cy5 and Cy3 CyDye conjugated antirabbit and mouse IgG secondary antibodies (1:2,500 dilution, GE Healthcare). After the washing steps in TBS-T and later in TBS the bands were visualized using a Typhoon TRIO+ 
scanner. Fluorescence intensities were quantified using the ImageQuant TL software. The densitometry data of protein band intensities were analyzed with Image J software (NIH, Bethesda). Densitometric values of the APOE protein bands were normalized to the average densities of the synaptophysin (SYP) in the same sample. Differences between $\mathrm{CCH}$ and control synaptosome samples were statistically analyzed using independent Student's t-test.

\section{Results}

\section{Magnetic Resonance Angiography}

Magnetic resonance angiography studies show that the blood flow in the carotis arteries were successfully blocked bilaterally in all $\mathrm{CCH}$ animals while it remained unaffected in the sham operated control rats (Fig. 1). The thickening of vertebro-basilar arteries was also observed in each $\mathrm{CCH}$ animal due to the BCCAO.
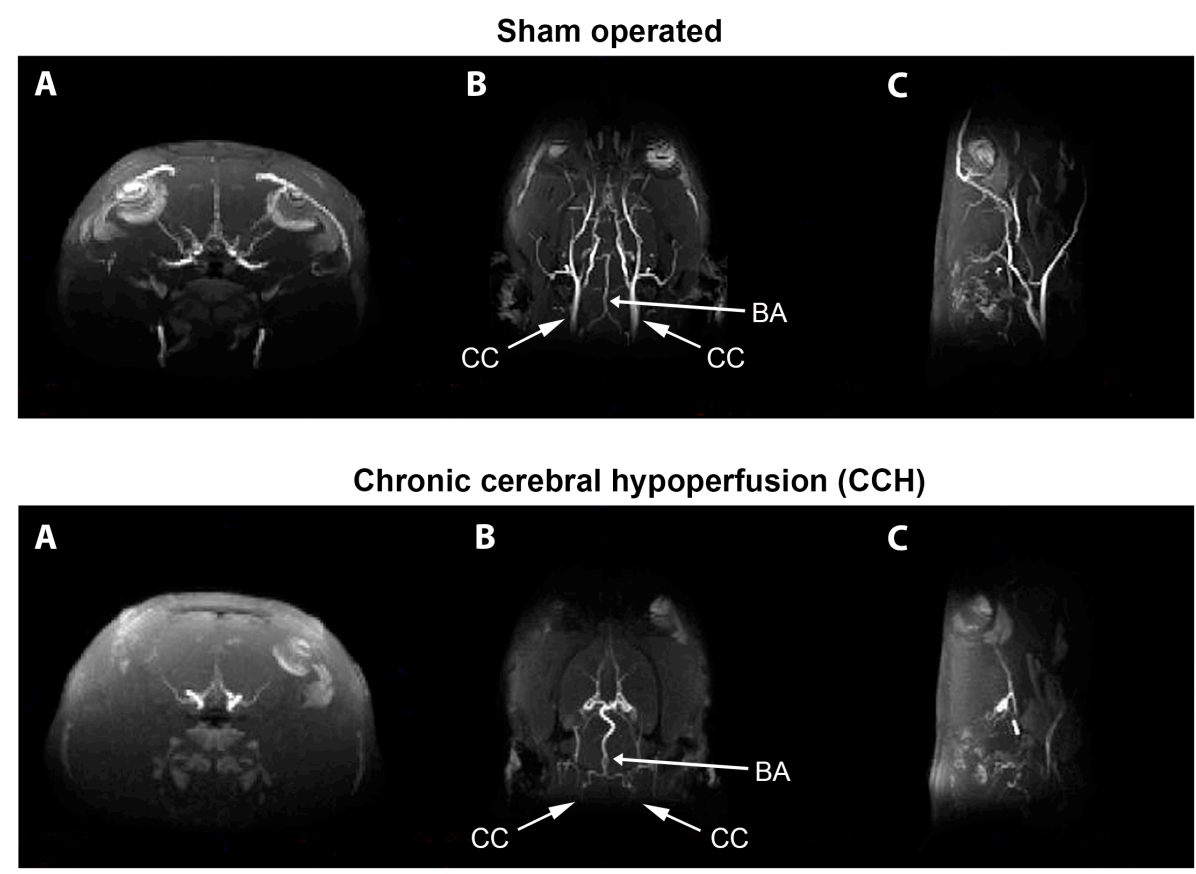

Figure 1. Magnetic resonance angiography (MRA) of sham operated control (above) and chronic cerebral hypoperfusion $(\mathrm{CCH})$ rat brain (below). Coronal (A), horizontal (B) and sagittal (C) views are shown at appropriate levels. Arteries with blood flow appear white in 
the images. Successful occlusion of common carotid arteries (CC) and thickening of the vertebro-basilar artery $(\mathrm{BA})$ are visible in $\mathrm{CCH}$ rats.

\section{Validation of the purity of the synaptosome preparation with electron microscope}

Electron microscopic analysis revealed that the samples consist of synaptosomes containing characteristic pre- and postsynaptic elements. Presynaptic endings contain synaptic vesicles and mitochondria. Postsynaptic elements were attached to most of the sealed presynaptic terminals. Nucleus or cell body related compartment (lysosomes and Golgi apparatus) were not present in the samples suggesting the purity and enrichment of the synaptosome preparation (Fig. 2).

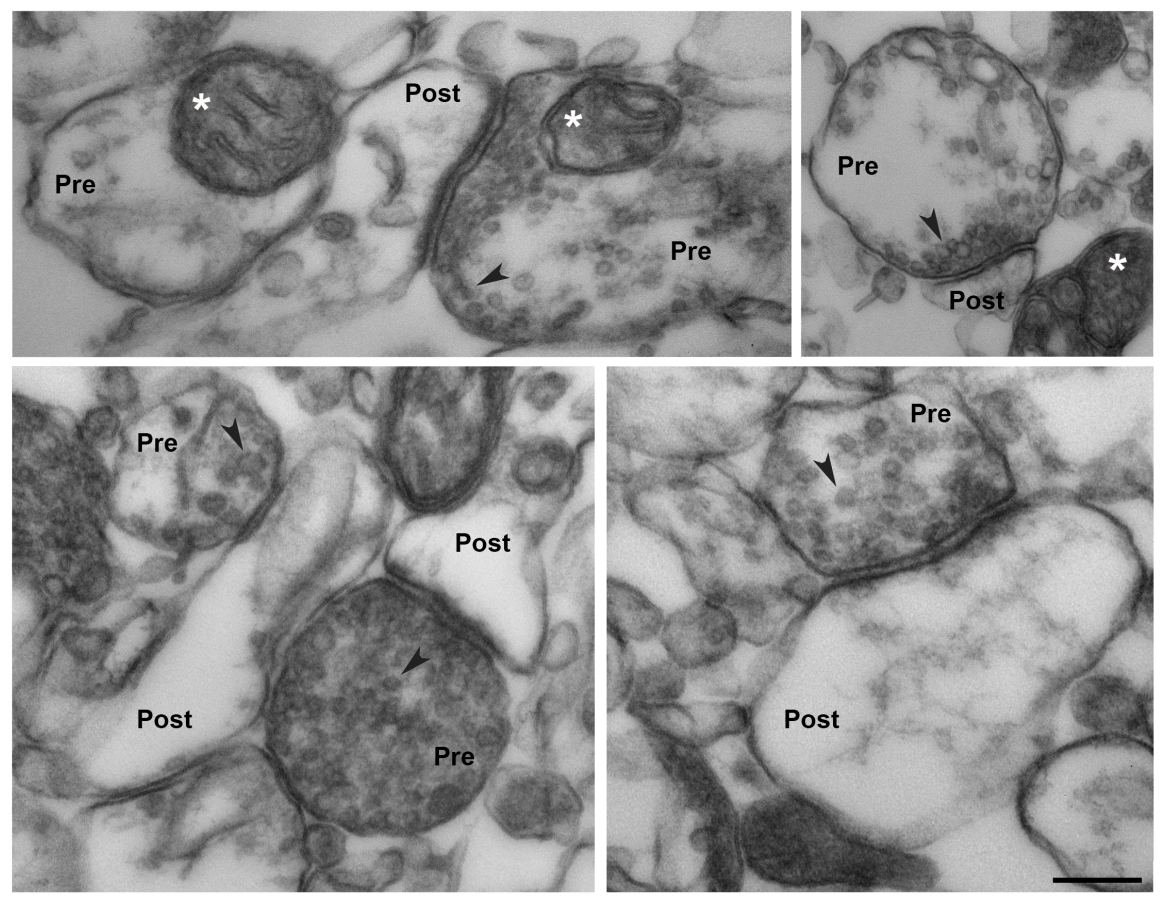

Figure 2. Electron microscopic images of the synaptosome preparations. The images show synaptic vesicle and mitochondria containing sealed presynaptic terminals and postsynaptic regions attached to postsynaptic densities. Synaptic endings fill the majority of the preparations. *: synaptic mitochondria, arrowheads show synaptic vesicles. Scale bar: $1 \mu \mathrm{m}$ 


\section{Functional clusters of altered proteins}

In the present study, we identified (with at least 3 peptides) 23 proteins with significantly increased (Table 1) and 23 proteins with decreased (Table 2) expression level by more than \pm 1.3 -fold change in $\mathrm{CCH}$ rats compared to sham operated control animals (ttest, $\mathrm{P}<0.05$ ). Fold changes of the altered proteins were in the range of -1.73 to +1.55 . To graphically represent the significance and magnitude of protein changes, volcano plot $\log 10$ (P-value) vs. $\log 2$ (fold change of hypoperfusion / control group) - was constructed. Points above the non-axial horizontal line represent proteins with significantly different abundances $(\mathrm{P}<0.05)$. Points to the left of the left non-axial vertical line indicate protein fold changes of hypoperfusion / control less than -1.3 , while points to the right of the right nonaxial vertical line label protein fold changes of hypoperfusion / control greater than +1.3 (Fig. 3).

The proteins showing increased expression levels participate in a variety of metabolic processes, including protein biosynthesis and folding $(n=6)$; ubiquitin-mediated degradation $(n=4)$; lipid metabolism $(n=4)$; GABA-shunt $(n=3)$; ion transport and homeostasis $(n=2)$; MAPK signalling pathway $(n=2)$; mitochondrial transport $(n=1)$ and nucleotide metabolism $(n=1)$ based on GeneOntology database. Expressions of protein biosynthesis and folding related proteins changed to the greatest extent (Table 1).

The proteins with decreased expression level after $\mathrm{CCH}$ participate in a variety of synaptic processes including synaptic vesicle cycle $(n=5)$; synaptic assembly $(n=3)$; GABAerg neurotransmission $(n=3)$; ion transport and homeostasis $(n=4)$; neurogenesis $(n=3)$; cell adhesion $(n=3)$; complement regulation $(n=1)$ and mitochondrial transport $(n=1)$. Expressions of synapse assembly and neurotransmission related proteins decreased to the greatest extent. (Table 2). 


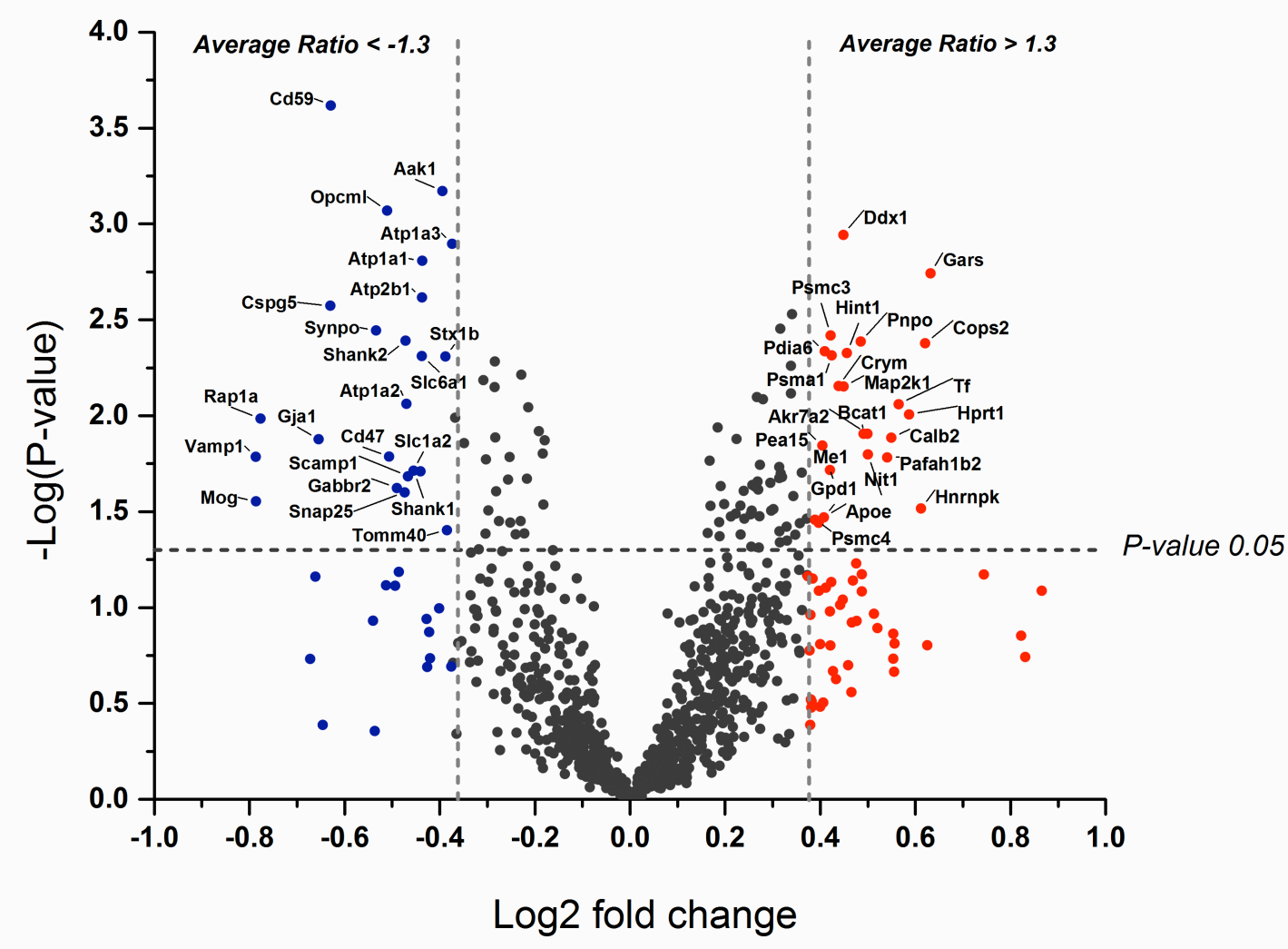

Figure 3. Volcano plot illustrates magnitude and significance of the protein comparisons between the hypoperfusion and control groups. The $-\log 10$ ( $\mathrm{P}$ value) is plotted against the $\log 2$ (fold change: hypoperfusion / control group). The non-axial vertical lines denote \pm 1.3 fold change while the non-axial horizontal line denotes $\mathrm{P}=0.05$ significance threshold (prior to logarithmic transformation). Significantly altered proteins with more than \pm 1.3 -fold change are highlighted with gene names. 
Table 1.

\begin{tabular}{|c|c|c|c|c|c|c|c|}
\hline Gene & Protein name & AR & p-value & PN & SC\% & Localisation & Synaptic function \\
\hline \multicolumn{8}{|c|}{ Protein biosynthesis and folding } \\
\hline GARS & Glycine--tRNA ligase & 1.55 & 0.002 & 8 & 21.8 & $\mathrm{cp}$, ax, mit & $\begin{array}{l}\text { dendritic and axonal terminal } \\
\text { arborization (1) }\end{array}$ \\
\hline HNRNPK & Heterogeneous nuclear ribonucleoprotein $\mathrm{K}$ & 1.53 & 0.030 & 10 & 34.1 & $\mathrm{cp}$, syn, mit & $\begin{array}{l}\text { synaptic transmission, spine } \\
\text { development ( } 2 \text { ) }\end{array}$ \\
\hline NIT1 & Nitrilase homolog 1 & 1.41 & 0.016 & 6 & 36.0 & mit, $c p$ & apoptosis (GO) \\
\hline HINT1 & Histidine triad nucleotide-binding protein 1 & 1.37 & 0.005 & 5 & 60.3 & $\mathrm{cp}$ & apoptosis (GO) \\
\hline DDX1 & ATP-dependent RNA helicase DDX1 & 1.36 & 0.001 & 11 & 26.8 & $\mathrm{cp}$ & interaction with HNRNPK (3) \\
\hline PDIA6 & Protein disulfide-isomerase $A 6$ & 1.33 & 0.005 & 6 & 20.2 & m, ER, syn & $\begin{array}{l}\text { protective role agains hypoxia and } \\
\text { misfolded proteins (4) }\end{array}$ \\
\hline \multicolumn{8}{|c|}{ Ubiquitin mediated protein degradation } \\
\hline COPS2 & COP9 signalosome complex subunit 2 & 1.54 & 0.004 & 6 & 22.1 & $\mathrm{cp}$ & neuron differentation (GO) \\
\hline PSMA1 & Proteasome subunit alpha type-1 & 1.34 & 0.005 & 7 & 43.3 & $\mathrm{cp}$ & synaptic elimination (5) \\
\hline PSMC3 & $26 \mathrm{~S}$ protease regulatory subunit $6 \mathrm{~A}$ & 1.34 & 0.004 & 9 & 32.8 & $\mathrm{cp}$ & ATP-dependent degradation of \\
\hline PSMC4 & $26 \mathrm{~S}$ protease regulatory subunit $6 \mathrm{~B}$ & 1.31 & 0.035 & 7 & 42.3 & $\mathrm{cp}$ & \\
\hline \multicolumn{8}{|c|}{ GABA-shunt } \\
\hline AKR7A2 & Aflatoxin B1 aldehyde reductase member 2 & 1.41 & 0.012 & 5 & 21.0 & $\mathrm{cp}$, Golgi & $\begin{array}{l}\text { GABA degradation, gamma- } \\
\text { hydroxybutyrate production ( } 7 \text { ) }\end{array}$ \\
\hline BCAT1 & $\begin{array}{l}\text { Branched-chain-amino-acid } \\
\text { aminotransferase, cytosolic }\end{array}$ & 1.41 & 0.012 & 10 & 47.4 & $\mathrm{cp}$ & glutamate-GABA metabolism (8) \\
\hline PNPO & Pyridoxine-5-phosphate oxidase & 1.40 & 0.004 & 3 & 16.1 & $\mathrm{cp}$ & Glutamate and GABA synthesis (9) \\
\hline \multicolumn{8}{|c|}{ Lipid metabolism } \\
\hline PAFAH1B2 & $\begin{array}{l}\text { Platelet-activating factor acetylhydrolase IB } \\
\text { subunit beta }\end{array}$ & 1.45 & 0.016 & 8 & 68.6 & $\mathrm{cp}$ & $\begin{array}{l}\text { brain development, neuronal migration } \\
\text { (10) }\end{array}$ \\
\hline APOE & Apolipoprotein E & 1.33 & 0.034 & 10 & 41.0 & secr & $\begin{array}{l}\text { neuroregeneration under } \\
\text { hypoperfusion, axonal growth (11) }\end{array}$ \\
\hline ME1 & NADP-dependent malic enzyme & 1.34 & 0.019 & 14 & 44.4 & mit, $\mathrm{cp}$ & $\begin{array}{l}\text { glutathion metabolism, pyruvate } \\
\text { recycling pathway (15) }\end{array}$ \\
\hline GPD1 & $\begin{array}{l}\text { Glycerol-3-phosphate dehydrogenase } \\
\text { [NAD (+)], cytoplasmic }\end{array}$ & 1.32 & 0.036 & 12 & 57.0 & $\mathrm{cp}$, mit & $\begin{array}{l}\text { connection between carbohydrate and } \\
\text { lipid metabolism (GO) }\end{array}$ \\
\hline \multicolumn{8}{|c|}{ MAPK signaling pathway } \\
\hline MAP2K1 & $\begin{array}{l}\text { Dual specificity mitogen-activated protein } \\
\text { kinase kinase } 1\end{array}$ & 1.37 & 0.007 & 14 & 58.0 & $\mathrm{~m}, \mathrm{cp}$ & $\begin{array}{l}\text { neuron differentiation and projection } \\
\text { (GO) }\end{array}$ \\
\hline PEA15 & Astrocytic phosphoprotein PEA-15 & 1.32 & 0.014 & 5 & 44.6 & $\mathrm{cp}$ & apoptosis (GO) \\
\hline \multicolumn{8}{|c|}{ Ion transport and homeostasis } \\
\hline TF & Serotransferrin & 1.48 & 0.009 & 16 & 29.5 & $\mathrm{cp}, \mathrm{m}$, secr & $\begin{array}{l}\text { apoptosis, hypoxia, ferric ion transport } \\
\text { (GO) }\end{array}$ \\
\hline CALB2 & Calretinin & 1.46 & 0.013 & 9 & 42.1 & syn, $c p$ & $\begin{array}{l}\text { synaptic transmission, LTP, calcium ion } \\
\text { binding (16) }\end{array}$ \\
\hline \multicolumn{8}{|c|}{ Nucleotide metabolism } \\
\hline HPRT1 & $\begin{array}{l}\text { Hypoxanthine-guanine } \\
\text { phosphoribosyltransferase }\end{array}$ & 1.50 & 0.010 & 8 & 45.9 & $\mathrm{cp}$ & brain development (GO) \\
\hline \multicolumn{8}{|c|}{ Mitochondrial transport } \\
\hline CRYM & Ketimine reductase mu-crystallin & 1.36 & 0.007 & 10 & 60.7 & $\mathrm{cp}$ & $\begin{array}{l}\text { regulation of the free intracellular } \\
\text { concentration of triiodothyronine (GO) }\end{array}$ \\
\hline
\end{tabular}


Table 2.

\begin{tabular}{|c|c|c|c|c|c|c|c|}
\hline Protein ID & Protein name & AR & p-value & PN & SC\% & Localisation & Synaptic function \\
\hline \multicolumn{8}{|c|}{ Synaptic vesicle cycle } \\
\hline VAMP1 & Vesicle-associated membrane protein 1 & -1.73 & 0.016 & 3 & 33.9 & ves, syn & $\begin{array}{l}\text { SNARE assembly, vesicle targeting and } \\
\text { fusion (GO) }\end{array}$ \\
\hline SNAP25 & Synaptosomal-associated protein 25 & -1.39 & 0.025 & 16 & 68.4 & ves, pre & $\begin{array}{l}\text { vesicle docking and fusion, } \\
\text { neurotransmitter release (GO) }\end{array}$ \\
\hline STX1B & Syntaxin-1B & -1.31 & 0.005 & 17 & 59.4 & ves, pre & vesicle docking (GO) \\
\hline AAK1 & AP2-associated protein kinase 1 & -1.31 & 0.001 & 21 & 41.8 & pre, $m$ & $\begin{array}{l}\text { synaptic vesicle recycling, receptor- } \\
\text { mediated endocytosis (GO) }\end{array}$ \\
\hline SCAMP1 & $\begin{array}{l}\text { Secretory carrier-associated membrane } \\
\text { protein } 1\end{array}$ & -1.38 & 0.021 & 5 & 26.0 & ves, Golgi, m & protein transport, endocytosis (GO) \\
\hline \multicolumn{8}{|c|}{ Ion transport and homeostasis } \\
\hline ATP2B1 & $\begin{array}{l}\text { Plasma membrane calcium-transporting } \\
\text { ATPase } 1\end{array}$ & -1.35 & 0.002 & 43 & 42.1 & $\begin{array}{l}\text { m, ER, Golgi, } \\
\text { syn }\end{array}$ & $\begin{array}{l}\text { ATP hydrolysis coupled calcium ion } \\
\text { transport (GO) }\end{array}$ \\
\hline ATP1A2 & $\begin{array}{l}\text { Sodium/potassium-transporting ATPase } \\
\text { subunit alpha-2 }\end{array}$ & -1.38 & 0.009 & 50 & 52.1 & m, syn, cp & \\
\hline ATP1A1 & $\begin{array}{l}\text { Sodium/potassium-transporting ATPase } \\
\text { subunit alpha-1 }\end{array}$ & -1.35 & 0.002 & 50 & 52.3 & $\mathrm{~m}$ & $\begin{array}{l}\text { ATP hydrolysis coupled sodium and } \\
\text { potassion ion transport (GO) }\end{array}$ \\
\hline АTP1А3 & $\begin{array}{l}\text { Sodium/potassium-transporting ATPase } \\
\text { subunit alpha-3 }\end{array}$ & -1.30 & 0.001 & 55 & 62.4 & $\mathrm{~m}$ & \\
\hline \multicolumn{8}{|c|}{ Synaptic assembly } \\
\hline SYNPO & Synaptopodin & -1.45 & 0.004 & 16 & 29.2 & syn, PSD & $\begin{array}{l}\text { motility of dendritic spines, actin } \\
\text { filament bundle assembly (GO) }\end{array}$ \\
\hline SHANK2 & $\begin{array}{l}\text { SH3 and multiple ankyrin repeat domains } \\
\text { protein } 2\end{array}$ & -1.39 & 0.004 & 22 & 30.4 & $\mathrm{cp}, \mathrm{PSD}$ & organization of the dendritic spine and \\
\hline SHANK1 & $\begin{array}{l}\text { SH3 and multiple ankyrin repeat domains } \\
\text { protein } 1\end{array}$ & -1.37 & 0.019 & 17 & 14.3 & $\mathrm{cp}, \mathrm{PSD}$ & synaptic junction (GO) \\
\hline \multicolumn{8}{|c|}{ GABA/glutamatergic transmission } \\
\hline GABBR2 & $\begin{array}{l}\text { Gamma-aminobutyric acid type B receptor } \\
\text { subunit } 2\end{array}$ & -1.40 & 0.024 & 5 & 9.5 & syn, PSD, m & $\begin{array}{l}\text { G-protein coupled GABA receptor } \\
\text { activity }(\mathrm{GO})\end{array}$ \\
\hline SLC6A1 & $\begin{array}{l}\text { Sodium- and chloride-dependent GABA } \\
\text { transporter } 1\end{array}$ & -1.35 & 0.005 & 8 & 22.4 & pre, ves & $\begin{array}{l}\text { GABA reuptake into presynaptic } \\
\text { terminals }(\mathrm{GO})\end{array}$ \\
\hline SLC1A2 & Excitatory amino acid transporter 2 & -1.36 & 0.019 & 18 & 35.6 & pre & $\begin{array}{l}\text { released glutamate removing from the } \\
\text { synaptic cleft (GO) }\end{array}$ \\
\hline \multicolumn{8}{|c|}{ Neurogenesis } \\
\hline RAP1A & Ras-related protein Rap-1A & -1.71 & 0.010 & 7 & 50.0 & syn, cp, m & $\begin{array}{l}\text { neuron projection development, } \\
\text { vasculogenesis (GO) }\end{array}$ \\
\hline GJA1 & Gap junction alpha-1 protein & -1.57 & 0.013 & 9 & 31.2 & pm, ER, OMM & neuron projection (GO) \\
\hline CSPG5 & Chondroitin sulfate proteoglycan 5 & -1.55 & 0.003 & 6 & 16.1 & $\begin{array}{l}\text { syn, ER, Golgi, } \\
\text { m }\end{array}$ & $\begin{array}{l}\text { axon regeneration, growth regulation } \\
\text { (GO) }\end{array}$ \\
\hline \multicolumn{8}{|c|}{ Cell adhesion } \\
\hline MOG & Myelin-oligodendrocyte glycoprotein & -1.72 & 0.028 & 6 & 25.7 & $\mathrm{~m}$ & cell-cell communication (GO) \\
\hline OPCML & $\begin{array}{l}\text { Opioid-binding protein/cell adhesion } \\
\text { molecule }\end{array}$ & -1.42 & 0.001 & 11 & 42.0 & $\mathrm{~m}$ & synaptogenesis (GO) \\
\hline CD47 & Leukocyte surface antigen CD47 & -1.42 & 0.016 & 6 & 19.5 & $\mathrm{~m}$ & synaptic plasticity (GO) \\
\hline \multicolumn{8}{|c|}{ Complement regulation } \\
\hline CD59 & CD59 glycoprotein & -1.55 & 0.000 & 3 & 23.0 & $\mathrm{~m}$ & \\
\hline \multicolumn{8}{|c|}{ Mitochondrial transport } \\
\hline TOMM40 & $\begin{array}{l}\text { Mitochondrial import receptor subunit } \\
\text { TOM40 homolog }\end{array}$ & -1.31 & 0.039 & 9 & 39.3 & OMM & $\begin{array}{l}\text { import of protein precursors and ions } \\
\text { into mitochondria }(\mathrm{GO})\end{array}$ \\
\hline
\end{tabular}


Table 1. Significantly increased synaptic proteins in the cerebral cortex of $\mathrm{CCH}$ rats assigned to functional clusters. The red color gradient is used to show the degree of difference in the abundance of each proteins compared to the control group. Abbreviations: AR: average ratio, PN: unique peptides number, SC \%: sequence coverage percentage.

(1) - (Chihara et al., 2007), (2) - (Folci et al., 2014), (3) - (Chen et al., 2002), (4) - (Tanaka et al., 2000), (5) - (Ding and Shen, 2008), (6) - (Na et al., 2012), (7) - (Lyon et al., 2007), (8) (Sweatt et al., 2004), (9) - (Bahn et al., 2002), (10) - (Manya et al., 1998), (11) - (Kamada et al., 2003), (12) - (McKenna et al., 2000), (13) - (Christel et al., 2012), (GO) - According to Gene Ontology database.

Table 2. Significantly decreased synaptic proteins in the cerebral cortex of $\mathrm{CCH}$ rats assigned to functional clusters. The blue color gradient is used to show the degree of differential decreasing abundances of $\mathrm{CCH}$ proteins, compared to sham operated rats. Abbreviations: AR: average ratio, $\mathrm{PN}$ : unique peptides number, $\mathrm{SC} \%$ : sequence coverage percentage. (GO) According to Gene Ontology database.

\section{Western blot}

WB analysis was performed for APOE in the synaptosome fraction of cerebral cortex (Fig. 4). The protein expression of APOE $(2.32 \pm 0.78)$ showed significant increasing level in the $\mathrm{CCH}$ synapse compared to the synapse from the sham operated control rats $(\mathrm{p}<0.05)$. Thus, the WB results of APOE protein confirmed the LC-MS/MS data. 


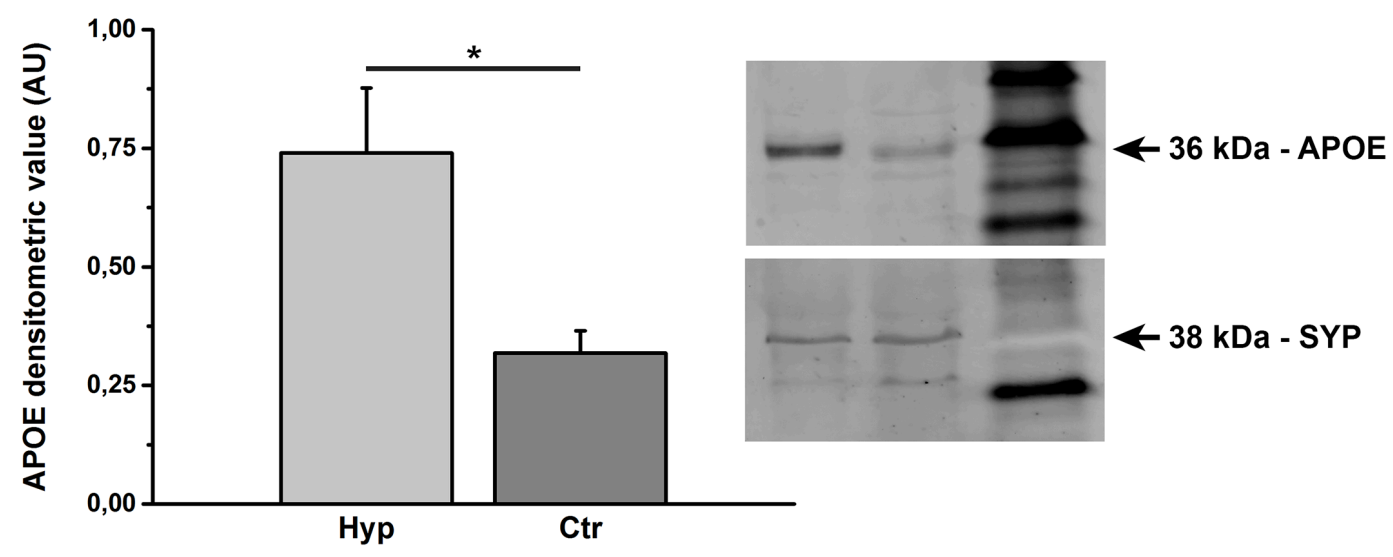

Figure 4. Validation of the increased expression of APOE in synapse. Immunopositive bands are shown at $36 \mathrm{kDa}$ for $\mathrm{APOE}$, and $38 \mathrm{kDa}$ for SYP loading control. Densitometric analysis was performed for APOE $(n=6)$. The expression of APOE was significantly increased in the $\mathrm{CCH}$ synapse compared to the synapse from the sham operated control rats $(*$ : $p<0.05)$. Error bars indicate s.e.m.

\section{Discussion}

Angiography of rats in our study represents a thorough control of the occlusion procedure. Indeed, blood supply by the carotid arteries was blocked in all animals. Blood supply to the brain by other routes including the visibly thickened vertebro-basilar artery compatible with the progressive process of vascular remodelling (Soria et al., 2013). Our results indicate that these adaptations are accompanied by alteration of the synaptic protein content. The electron microscopic imaging demonstrated that our synaptosome preparation contained sealed presynaptic terminals and postsynaptic vacuoles with intact synaptic specialization suggesting that the altered proteins are located in these compartments. Validation of APOE level was done by Western blotting, which indeed demonstrated an increased level of the protein following $\mathrm{CCH}$. 
The altered proteins belong to several functional categories. It is noteworthy that proteins belonging to the same functional category all increased or decreased their levels in $\mathrm{CCH}$ animals. This allows interpretation of changes of the particular functional processes in the synapse, rather than only individual proteins. Reduced synaptic vesicle cycle, synaptic assembly and ion transport, as well as the increased protein and lipid metabolism suggest a number of possible mechanisms of this transition (Fig. 5).
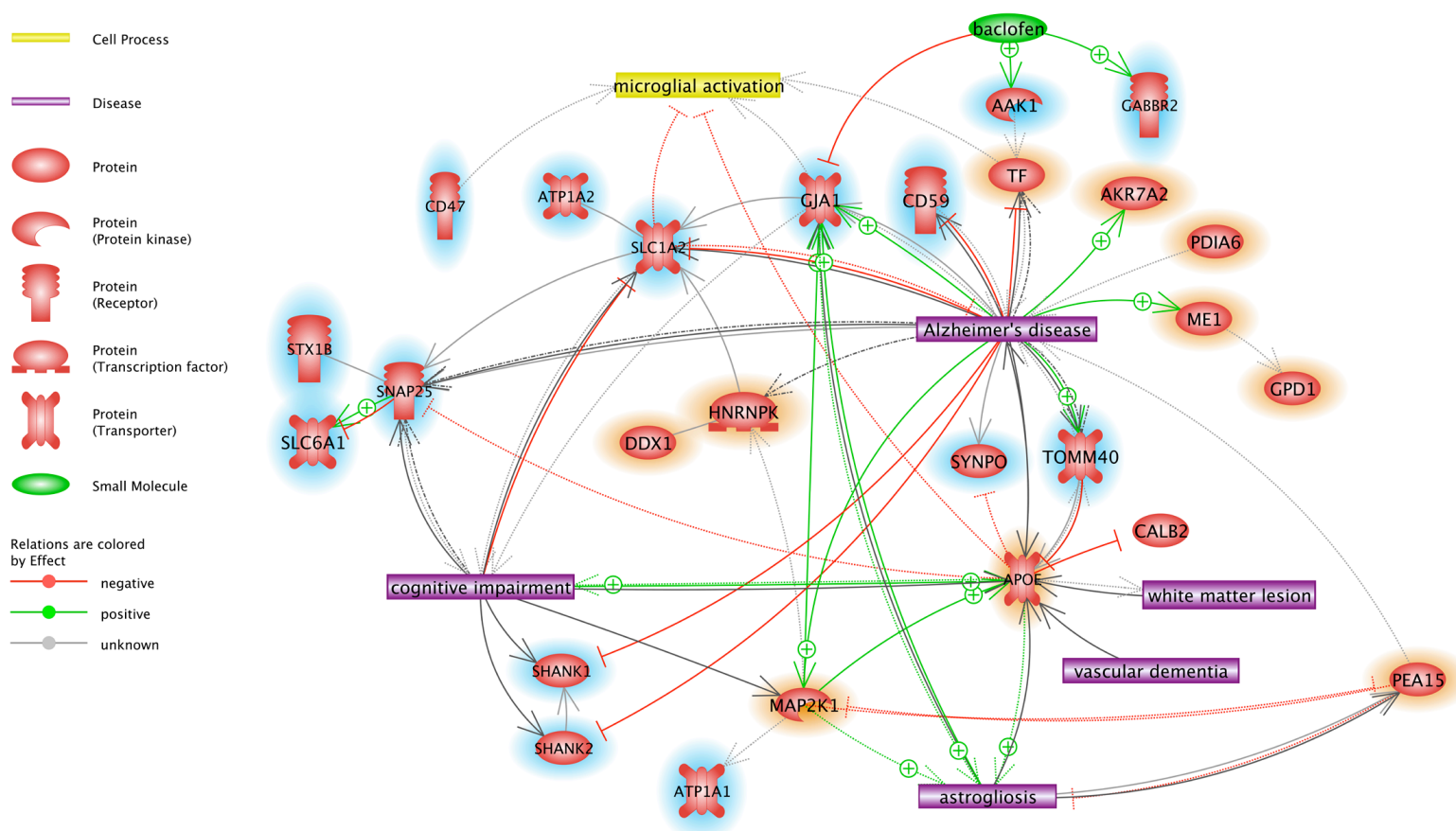

Figure 5. Connections of significantly altered synaptic proteins to $\mathrm{CCH}$ induced main neuropathological alterations and diseases. Red or blue highlights indicate synaptic proteins increased or decreased by $\mathrm{CCH}$. Green or red arrows indicate the positive or negative regulation between the proteins.

Chronic cerebral hypoperfusion effects on GABAergic / glutamatergic synaptic communication 
A number of synaptic transmission related proteins showed decreased level in $\mathrm{CCH}$ rats. They participate both in the release and reuptake of amino acid neurotransmitters. Among them three GABAergic / glutamatergic transmission related proteins showed decreased protein level: Excitatory amino acid transporter 2 (SLC1A2), Sodium- and chloride-dependent GABA transporter 1 (SLC6A1) and Gamma-aminobutyric acid type B receptor subunit 2 (GABABR2). According to published electron microscopic studies, SLC1A2 is mainly present in astrocytic soma and processes surrounding capillaries and axon terminals mainly around glutamatergic synapses, consistent with its role in facilitating glutamate reuptake and limiting glutamate spillover (Roberts et al., 2014). SLC6A1 immunoreactivity is mainly present in axon terminals of symmetrical synapses in the cortex, suited for GABA recycling in the presynaptic terminals following a release event, which is essential to sustain GABAergic synaptic transmission (Scimemi, 2014). Metabotropic GABA receptors are coupled to second-messenger systems through G-proteins and mediate slow and prolonged inhibitory effects (Misgeld et al., 1995). Electron microscopic studies showed that GABABR2 is more abundant on postsynaptic than presynaptic side with a dominant extrasynaptic membrane localization. Moreover, besides its main GABAergic synaptic localization it is also associated with putative glutamatergic synapses suggesting its involvement in both GABAergic and glutamatergic neurotransmission (Kulik et al., 2003). Consistent with our results, GABABR2 showed decreased cell surface expression in the hippocampus of BCCAO rats, which showed significant cognitive impairment (Lu et al., 2016).

Baclofen, a GABABR agonist, improved the down-regulation of GABABR2 expression associated with cognitive impairment ( $\mathrm{Lu}$ et al., 2016) and special working memory impairment (Luo et al., 2016), while also reversed neuronal damage with autophagy regulation under chronic cerebral hypoperfusion (Liu et al., 2015). Similar to our synaptic 
results, AP2-associated protein kinase 1 (AAK1) expression was significantly reduced in the hippocampal CA1 region under chronic cerebral hypoperfusion, which could be restored by baclofen to the control level (Li et al., 2014) (Fig. 5).

In the present study, three $\gamma$-aminobutiric acid (GABA) shunt related proteins showed increasing protein level in the cortical synapse of $\mathrm{CCH}$ rats: pyridoxine-5-phosphate oxidase (PNPO), branched-chain-amino-acid aminotransferase, cytosolic (BCAT1) and aflatoxin B1 aldehyde reductase member 2 (ARK72) (or succinic semialdehyde reductase, SSAR) (Fig. 5). PNPO catalyzes the oxidation of pyridoxine 5'-phosphate (PNP) into pyridoxal 5'-phosphate (PLP) which is an allosteric cofactor of BCAT1 and glutamate decarboxylase (GAD) enzymes (Bahn et al., 2002). BCAT1 is localized exclusively in neurons in the adult rat brain and catalyzes the reversible transamination of $\alpha$-ketoglutarate to glutamate while GAD catalyzes the decarboxylation of glutamate to GABA (Sweatt et al., 2004). GABA degradation has an important role in glutamate- and GABA-erg balance and generates succinic semialdehyde (SSA) intermediate via the activation of GABA transaminase (GABAT). SSA is normally converted to succinate through the activation of succinic semialdehyde dehydrogenase (SSADH). However, upon activation of ARK72, SSA is converted to GHB, as an alternative route from the GABA shunt (Picklo et al., 2001).

\section{APOE-mediated synaptic effects of chronic cerebral hypoperfusion}

APOE showed increased level in the synapse of $\mathrm{CCH}$ rats. It is indeed known to be released from neurons as the consequence of injury or stress (Huang and Mucke, 2012). The expression of APOE is significantly increased with AD compared to control brain (Linnertz et al., 2014). Furthermore, clinical studies revealed that AD patients have significantly lower APOE serum levels but higher cerebrospinal fluid levels compared to healthy (Laske, 2012, Martinez-Morillo et al., 2014). APOE4-positive AD individuals are often associated with 
impaired neurotransmission and elevated $\beta$-amyloid levels (Verret et al., 2012). APOE can contribute to reduced neurotransmission as it diminishes glutamate receptor function and synaptic plasticity (Chen et al., 2010).

Bioinformatical analysis suggests a central role of APOE in additional synaptic protein changes connected to AD (Linnertz et al., 2014) (Fig. 5). APOE, showing significantly decreased expression in our paradigm, interacts with mitochondrial import receptor subunit TOMM40 homolog (TOMM40), which causes mitochondrial impairment and neurotoxicity (Roses et al., 2014). In reverse, polymorphisms in TOMM40 has an effect on the levels of APOE in the cerebrospinal fluid of non-demented individuals and in the hippocampus of AD patients (Maruszak et al., 2012). Moreover, mutations in TOMM40 gene are important risk factors for AD (Dhillon and Fenech, 2014).

Several pre- (e.g. synaptotagmin, synaptophysin) and postsynaptic proteins including synaptopodin (SYNPO), which were downregulated in $\mathrm{CCH}$ rats, are also known to be downregulated in the brain of AD patients (Reddy et al., 2005). APOE4 gene expression inactivates the gene transcription of SYNPO and some other proteins involved in synaptic plasticity, synaptic regeneration and remodeling (Xu et al., 2007). SYNPO is an actinassociated protein playing role in modulating actin-based shape determination and essential to the formation of spine apparatuses of neurons, which are involved in synaptic plasticity (Yamazaki et al., 2001). The decreased protein level of SYNPO in CCH rats indicates the inhibitory effect of $\mathrm{CCH}$ on spine formation and synaptic plasticity. APOE genotype correlates with synaptosomal-associated protein 25 (SNAP25) depletion in frontotemporal lobar degeneration (Connelly et al., 2011), which showed decreased expression in CCH rat synapses. Clinical data has already described the reduced level of SNAP25 protein in AD suggesting its role in impaired neurotransmission (Furuya et al., 2012), which was also strengthened by the fact that single nucleotide polymorphisms are associated with functional 
MRI parameters in AD (Guerini et al., 2014). SNAP25 increases the surface expression of sodium- and chloride-dependent GABA transporter 1 (SLC6A1) (Fan et al., 2006). Moreover, SNAP25 and syntaxin 1B (STX1B) are able to interact with each other (Chapman et al., 1994).

White matter lesion, one of the main pathological consequence of $\mathrm{CCH}$, is also influenced by APOE genotype (Tapiola et al., 2008). Furthermore, CSF levels of APOE decreased with increasing degree of white matter lesion (Skoog et al., 1997).

\section{Relationships of chronic cerebral hypoperfusion altered synaptic proteins with cognitive impairment and dementia}

Gap junctional communication and Gap junction alpha-1 protein (GJA1) expression is affected in cerebral ischemia (Kielian and Esen, 2004) and in different stages of AD (Iacobas et al., 2005). Protein kinase C-induced ubiquitylation of GJA1 is partly mediated by the mitogen-activated protein kinase pathway (Leithe and Rivedal, 2004). GJA1, and specifically its C-terminal domain, is required for optimal LFA-1-mediated Ras-related protein Rap-1A (RAP1) activation and spreading (Machtaler et al., 2011). GJA1 directly regulates excitatory amino acid transporter 2 (SLC1A2) expression and function and modulates the activity of intracellular signal molecules, which in turn leads to its downregulation (Morioka et al., 2015). SLC1A2 activity is downregulated in AD brain (Boyd-Kimball et al., 2005), and show decreased protein level in $\mathrm{CCH}$ rats suggesting decreased degree of glutamate removal from the synaptic cleft. The decreasing SLC1A2 glutamate transporter and ATP1A2 ATPase are part of the same presynaptic macromolecular complex and operate as a functional unit to remove released glutamate from the synaptic cleft (Rose et al., 2009). The reduced glutamate reuptake in $\mathrm{CCH}$ rats suggests decreased GABA synthesis in the presynaptic region under hypometabolism. ATP1A1 is the catalytic component of the active enzyme, which catalyzes 
the hydrolysis of ATP coupled to the exchange of sodium and potassium ions across the plasma membrane creating their electrochemical gradient to provide energy for active transport of various nutrients. The $\mathrm{CCH}$-induced decreased ATPA1 level indicates downregulated synaptic transport during brain hypometabolism.

Mitogen-activated protein kinase kinase 1 (MAP2K1) has an important role in neuron differentiation and projection (Mace et al., 2013). The activity of MAPK signaling is markedly increased in AD brains (Rohe et al., 2008). The carbohydrate metabolism-related proteins showed increased protein level in $\mathrm{CCH}$ rats. Among them, the glucose transport regulator astrocytic phosphoprotein PEA-15 (PEA-15) protein may play a protective role in $\mathrm{AD}$ (Ahn et al., 2014) and is able to bind to MAP2K1. MAP2K1 phosphorylation drives cytoplasmic accumulation of heterogeneous nuclear ribonucleoprotein $\mathrm{K}$ (HNRPK or HNRNPK) synaptic transmission and spine development regulator protein (Habelhah et al., 2001), whose expression pattern is also correlated with AD progression (Liang et al., 2012). ATP-dependent RNA helicase DDX1 (DDX1) could interact with HNRPK which is known to be involved in the regulation of transcription, translation, nuclear transport, and signal transduction (Chen et al., 2002).

Serotransferrin (TF) glycosylation (Taniguchi et al., 2008) and aggregation (Booyjzsen et al., 2012) may play an important role in the pathophysiology of AD and also modulate the homeostasis of full-length APP (Khachaturian, 2008). Secretory carrierassociated membrane protein 1 (SCAMP1) and AP2-associated protein kinase 1 (AAK1) decreases the TF uptake by endocytosis suggesting their role in endocytosis via a mechanism, which may involve the recruitment of clathrin coats to the plasma membrane and the transGolgi network (Fernandez-Chacon et al., 2000, Conner and Schmid, 2002). Therefore, a decreasing level of SCAMP1 is consistent with increased TF expression in CCH synapse. 


\section{Chronic cerebral hypoperfusion inflammatory effects}

In the present study, several $\mathrm{CCH}$-induced synaptic protein changes have a strong relationship with microglia activation and / or astrocytosis (Fig. 5). Among them, GJA1, SLCA2 and Leukocyte surface antigen CD47 (CD47) showed decreased, while APOE, MAP2K1, TF and PEA-15 showed increased expression in $\mathrm{CCH}$ rats. Interestingly, downregulation or absence of GJA1 reduced neuronal loss, capillary fragmentation, astrocytosis and microglia activation (Davidson et al., 2013), while reactive astrogliosis increases GJA1 expression (Masaki et al., 2013, Wallach et al., 2014). Moreover, brain microgliosis and astrogliosis are also affected in APOE transgenic mice (Bales et al., 1999) and the absence of APOE dramatically reduced amyloid deposition and the resulting astrogliosis and microgliosis (Ophir et al., 2003). APOE co-localizes with $\beta$-amyloid in basement membrane drainage pathways in the walls of arteries. Furthermore, the attachment of ApoE4/ $\beta$-amyloid complexes to basement membrane laminin is significantly weaker than ApoE3/ $\beta$-amyloid complexes (Zekonyte et al., 2016). Several previous reports suggest the hypothesis that impaired APOE4 function modulates $\beta$ amyloid induced effects on inflammatory receptor signaling, including amplification of detrimental (toll-like receptor 4-p38 $\alpha$ ) and suppression of beneficial (IL-4R-nuclear receptor) pathways (Tai et al., 2015).

\section{Conclusion}

Cerebrovascular pathology is a major risk factor for cognitive dysfunction in the elderly, both on its own, and as a co-morbid pathology (Murphy et al., 2016). $\mathrm{CCH}$ is associated with altered levels of a number of synaptic proteins in the cerebral cortex. Synaptic metabolism and GABA-shunt related proteins are the major functional classes of proteins with increased expression, while neurotransmission and synaptic assembly related proteins showed the largest decreased protein levels. Bioinformatical analyses of the $\mathrm{CCH}$-altered 
proteins suggest an important role of APOE in mediating synaptic effect of $\mathrm{CCH}$. APOE showed an increasing synaptic level under $\mathrm{CCH}$, which was also confirmed with WB. Our identified synaptic protein changes preceding the onset of $\mathrm{AD}$ in the $\mathrm{CCH}$ model suggest their potential role in the progression of $\mathrm{AD}$.

\section{References}

Ahn EH, Kim DW, Shin MJ, Kim HR, Kim SM, Woo SJ, Eom SA, Jo HS, Kim DS, Cho SW, Park J, Eum WS, Choi SY (2014) PEP-1-PEA-15 protects against toxin-induced neuronal damage in a mouse model of Parkinson's disease. Biochimica et biophysica acta 1840:1686-1700.

Bahn JH, Kwon OS, Joo HM, Ho Jang S, Park J, Hwang IK, Kang TC, Won MH, Yil Kwon H, Kwok F, Kim HB, Cho SW, Choi SY (2002) Immunohistochemical studies of brain pyridoxine-5'-phosphate oxidase. Brain research 925:159-168.

Bales KR, Verina T, Cummins DJ, Du Y, Dodel RC, Saura J, Fishman CE, DeLong CA, Piccardo P, Petegnief V, Ghetti B, Paul SM (1999) Apolipoprotein E is essential for amyloid deposition in the APP(V717F) transgenic mouse model of Alzheimer's disease. Proceedings of the National Academy of Sciences of the United States of America 96:15233-15238.

Booyjzsen C, Scarff CA, Moreton B, Portman I, Scrivens JH, Costantini G, Sadler PJ (2012) Fibrillation of transferrin. Biochimica et biophysica acta 1820:427-436.

Borroni B, Anchisi D, Paghera B, Vicini B, Kerrouche N, Garibotto V, Terzi A, Vignolo LA, Di Luca M, Giubbini R, Padovani A, Perani D (2006) Combined 99mTc-ECD SPECT and neuropsychological studies in $\mathrm{MCl}$ for the assessment of conversion to AD. Neurobiology of aging 27:24-31.

Boyd-Kimball D, Castegna A, Sultana R, Poon HF, Petroze R, Lynn BC, Klein JB, Butterfield DA (2005) Proteomic identification of proteins oxidized by Abeta(1-42) in synaptosomes: implications for Alzheimer's disease. Brain research 1044:206-215.

Cankurtaran M, Yavuz BB, Cankurtaran ES, Halil M, Ulger Z, Ariogul S (2008) Risk factors and type of dementia: vascular or Alzheimer? Arch Gerontol Geriatr 47:25-34.

Cechetti F, Worm PV, Pereira LO, Siqueira IR, C AN (2010) The modified 2VO ischemia protocol causes cognitive impairment similar to that induced by the standard method, but with a better survival rate. Brazilian journal of medical and biological research $=$ Revista brasileira de pesquisas medicas e biologicas 43:1178-1183.

Chapman ER, An S, Barton N, Jahn R (1994) SNAP-25, a t-SNARE which binds to both syntaxin and synaptobrevin via domains that may form coiled coils. The Journal of biological chemistry 269:27427-27432.

Chen HC, Lin WC, Tsay YG, Lee SC, Chang CJ (2002) An RNA helicase, DDX1, interacting with poly(A) RNA and heterogeneous nuclear ribonucleoprotein $\mathrm{K}$. The Journal of biological chemistry 277:40403-40409.

Chen Y, Durakoglugil MS, Xian X, Herz J (2010) ApoE4 reduces glutamate receptor function and synaptic plasticity by selectively impairing ApoE receptor recycling. Proceedings of the National Academy of Sciences of the United States of America 107:12011-12016.

Chihara T, Luginbuhl D, Luo L (2007) Cytoplasmic and mitochondrial protein translation in axonal and dendritic terminal arborization. Nature neuroscience 10:828-837.

Christel CJ, Schaer R, Wang S, Henzi T, Kreiner L, Grabs D, Schwaller B, Lee A (2012) Calretinin regulates $\mathrm{Ca} 2+-$ dependent inactivation and facilitation of $\mathrm{Ca}(\mathrm{v}) 2.1 \mathrm{Ca} 2+$ channels through a 
direct interaction with the alpha12.1 subunit. The Journal of biological chemistry 287:3976639775.

Connelly SJ, Mukaetova-Ladinska EB, Abdul-All Z, Alves da Silva J, Brayne C, Honer WG, Mann DM (2011) Synaptic changes in frontotemporal lobar degeneration: correlation with MAPT haplotype and APOE genotype. Neuropathol Appl Neurobiol 37:366-380.

Conner SD, Schmid SL (2002) Identification of an adaptor-associated kinase, AAK1, as a regulator of clathrin-mediated endocytosis. The Journal of cell biology 156:921-929.

Davidson JO, Green CR, Bennet L, Nicholson LF, Danesh-Meyer H, O'Carroll SJ, Gunn AJ (2013) A key role for connexin hemichannels in spreading ischemic brain injury. Curr Drug Targets 14:3646.

de la Torre JC, Pappas BA, Prevot V, Emmerling MR, Mantione K, Fortin T, Watson MD, Stefano GB (2003) Hippocampal nitric oxide upregulation precedes memory loss and A beta 1-40 accumulation after chronic brain hypoperfusion in rats. Neurol Res 25:635-641.

Dhillon VS, Fenech M (2014) Mutations that affect mitochondrial functions and their association with neurodegenerative diseases. Mutat Res Rev Mutat Res 759:1-13.

Ding $M$, Shen $K$ (2008) The role of the ubiquitin proteasome system in synapse remodeling and neurodegenerative diseases. BioEssays : news and reviews in molecular, cellular and developmental biology 30:1075-1083.

Fan HP, Fan FJ, Bao L, Pei G (2006) SNAP-25/syntaxin 1A complex functionally modulates neurotransmitter gamma-aminobutyric acid reuptake. The Journal of biological chemistry 281:28174-28184.

Farkas E, Luiten PG, Bari F (2007) Permanent, bilateral common carotid artery occlusion in the rat: a model for chronic cerebral hypoperfusion-related neurodegenerative diseases. Brain Res Rev 54:162-180.

Fernandez-Chacon R, Achiriloaie M, Janz R, Albanesi JP, Sudhof TC (2000) SCAMP1 function in endocytosis. The Journal of biological chemistry 275:12752-12756.

Folci A, Mapelli L, Sassone J, Prestori F, D'Angelo E, Bassani S, Passafaro M (2014) Loss of hnRNP K impairs synaptic plasticity in hippocampal neurons. The Journal of neuroscience : the official journal of the Society for Neuroscience 34:9088-9095.

Furuya TK, Silva PN, Payao SL, Bertolucci PH, Rasmussen LT, De Labio RW, Braga IL, Chen ES, Turecki G, Mechawar N, Mill J, Smith MA (2012) Analysis of SNAP25 mRNA expression and promoter DNA methylation in brain areas of Alzheimer's Disease patients. Neuroscience 220:41-46.

Guerini FR, Agliardi C, Sironi M, Arosio B, Calabrese E, Zanzottera M, Bolognesi E, Ricci C, Costa AS, Galimberti D, Griffanti L, Bianchi A, Savazzi F, Mari D, Scarpini E, Baglio F, Nemni R, Clerici M (2014) Possible association between SNAP-25 single nucleotide polymorphisms and alterations of categorical fluency and functional MRI parameters in Alzheimer's disease. Journal of Alzheimer's disease : JAD 42:1015-1028.

Habelhah H, Shah K, Huang L, Ostareck-Lederer A, Burlingame AL, Shokat KM, Hentze MW, Ronai Z (2001) ERK phosphorylation drives cytoplasmic accumulation of hnRNP-K and inhibition of mRNA translation. Nature cell biology 3:325-330.

Hahn CG, Banerjee A, Macdonald ML, Cho DS, Kamins J, Nie Z, Borgmann-Winter KE, Grosser T, Pizarro A, Ciccimaro E, Arnold SE, Wang HY, Blair IA (2009) The post-synaptic density of human postmortem brain tissues: an experimental study paradigm for neuropsychiatric illnesses. PLoS One 4:e5251.

Huang Y, Mucke L (2012) Alzheimer mechanisms and therapeutic strategies. Cell 148:1204-1222.

lacobas DA, lacobas S, Urban-Maldonado M, Spray DC (2005) Sensitivity of the brain transcriptome to connexin ablation. Biochimica et biophysica acta 1711:183-196.

Jing Z, Shi C, Zhu L, Xiang Y, Chen P, Xiong Z, Li W, Ruan Y, Huang L (2015) Chronic cerebral hypoperfusion induces vascular plasticity and hemodynamics but also neuronal degeneration 
and cognitive impairment. Journal of cerebral blood flow and metabolism : official journal of the International Society of Cerebral Blood Flow and Metabolism 35:1249-1259.

Kamada H, Sato K, Zhang WR, Omori N, Nagano I, Shoji M, Abe K (2003) Spatiotemporal changes of apolipoprotein $\mathrm{E}$ immunoreactivity and apolipoprotein $\mathrm{E}$ mRNA expression after transient middle cerebral artery occlusion in rat brain. Journal of neuroscience research 73:545-556.

Khachaturian ZS (2008) Alzheimer's \& Dementia: the Journal of the Alzheimer's Association. Alzheimer's \& dementia : the journal of the Alzheimer's Association 4:315.

Kielian T, Esen N (2004) Effects of neuroinflammation on glia-glia gap junctional intercellular communication: a perspective. Neurochem Int 45:429-436.

Kulik A, Vida I, Lujan R, Haas CA, Lopez-Bendito G, Shigemoto R, Frotscher M (2003) Subcellular localization of metabotropic $G A B A(B)$ receptor subunits $G A B A(B 1 a / b)$ and $G A B A(B 2)$ in the rat hippocampus. The Journal of neuroscience : the official journal of the Society for Neuroscience 23:11026-11035.

Laske C (2012) Clinical and biomarker changes in Alzheimer's disease. N Engl J Med 367:2050; author reply 2051-2052.

Leithe E, Rivedal E (2004) Ubiquitination and down-regulation of gap junction protein connexin-43 in response to 12-0-tetradecanoylphorbol 13-acetate treatment. The Journal of biological chemistry 279:50089-50096.

Li CJ, Lu Y, Zhou M, Zong XG, Li C, Xu XL, Guo L, Lu Q (2014) Activation of GABAB receptors ameliorates cognitive impairment via restoring the balance of $H C N 1 / H C N 2$ surface expression in the hippocampal CA1 area in rats with chronic cerebral hypoperfusion. Mol Neurobiol 50:704-720.

Liang D, Han G, Feng X, Sun J, Duan Y, Lei H (2012) Concerted perturbation observed in a hub network in Alzheimer's disease. PLoS One 7:e40498.

Linnertz C, Anderson L, Gottschalk W, Crenshaw D, Lutz MW, Allen J, Saith S, Mihovilovic M, Burke JR, Welsh-Bohmer KA, Roses AD, Chiba-Falek O (2014) The cis-regulatory effect of an Alzheimer's disease-associated poly-T locus on expression of TOMM40 and apolipoprotein E genes. Alzheimer's \& dementia : the journal of the Alzheimer's Association 10:541-551.

Liu L, Li CJ, Lu Y, Zong XG, Luo C, Sun J, Guo LJ (2015) Baclofen mediates neuroprotection on hippocampal CA1 pyramidal cells through the regulation of autophagy under chronic cerebral hypoperfusion. Sci Rep 5:14474.

Lu Y, Li CJ, Chen C, Luo P, Zhou M, Li C, Xu XL, Lu Q, He Z, Guo LJ (2016) Activation of GABAB2 subunits alleviates chronic cerebral hypoperfusion-induced anxiety-like behaviours: A role for BDNF signalling and Kir3 channels. Neuropharmacology 110:308-321.

Luo P, Chen C, Lu Y, Fu T, Lu Q, Xu X, Li C, He Z, Guo L (2016) Baclofen ameliorates spatial working memory impairments induced by chronic cerebral hypoperfusion via up-regulation of HCN2 expression in the PFC in rats. Behavioural brain research 308:6-13.

Lyon RC, Johnston SM, Watson DG, McGarvie G, Ellis EM (2007) Synthesis and catabolism of gammahydroxybutyrate in SH-SY5Y human neuroblastoma cells: role of the aldo-keto reductase AKR7A2. The Journal of biological chemistry 282:25986-25992.

Mace PD, Wallez Y, Egger MF, Dobaczewska MK, Robinson H, Pasquale EB, Riedl SJ (2013) Structure of ERK2 bound to PEA-15 reveals a mechanism for rapid release of activated MAPK. Nature communications 4:1681.

Machtaler S, Dang-Lawson M, Choi K, Jang C, Naus CC, Matsuuchi L (2011) The gap junction protein Cx43 regulates B-lymphocyte spreading and adhesion. J Cell Sci 124:2611-2621.

Manya H, Aoki J, Watanabe M, Adachi T, Asou H, Inoue Y, Arai H, Inoue K (1998) Switching of platelet-activating factor acetylhydrolase catalytic subunits in developing rat brain. The Journal of biological chemistry 273:18567-18572. 
Martinez-Morillo E, Hansson O, Atagi Y, Bu G, Minthon L, Diamandis EP, Nielsen HM (2014) Total apolipoprotein $E$ levels and specific isoform composition in cerebrospinal fluid and plasma from Alzheimer's disease patients and controls. Acta neuropathologica 127:633-643.

Maruszak A, Peplonska B, Safranow K, Chodakowska-Zebrowska M, Barcikowska M, Zekanowski C (2012) TOMM40 rs10524523 polymorphism's role in late-onset Alzheimer's disease and in longevity. J Alzheimers Dis 28:309-322.

Masaki K, Suzuki SO, Matsushita T, Matsuoka T, Imamura S, Yamasaki R, Suzuki M, Suenaga T, Iwaki T, Kira J (2013) Connexin 43 astrocytopathy linked to rapidly progressive multiple sclerosis and neuromyelitis optica. PLoS One 8:e72919.

McKenna MC, Stevenson JH, Huang XL, Tildon JT, Zielke CL, Hopkins IB (2000) Mitochondrial malic enzyme activity is much higher in mitochondria from cortical synaptic terminals compared with mitochondria from primary cultures of cortical neurons or cerebellar granule cells. Neurochem Int 36:451-459.

Misgeld U, Bijak M, Jarolimek W (1995) A physiological role for GABAB receptors and the effects of baclofen in the mammalian central nervous system. Prog Neurobiol 46:423-462.

Morioka N, Zhang FF, Nakamura Y, Kitamura T, Hisaoka-Nakashima K, Nakata Y (2015) Tumor necrosis factor-mediated downregulation of spinal astrocytic connexin43 leads to increased glutamatergic neurotransmission and neuropathic pain in mice. Brain Behav Immun 49:293310.

Murphy MP, Corriveau RA, Wilcock DM (2016) Vascular contributions to cognitive impairment and dementia (VCID). Biochimica et biophysica acta 1862:857-859.

$\mathrm{Na} \mathrm{CH}$, Jones DR, Yang Y, Wang $\mathrm{X}, \mathrm{Xu} \mathrm{Y}$, Peng J (2012) Synaptic protein ubiquitination in rat brain revealed by antibody-based ubiquitome analysis. Journal of proteome research 11:47224732.

Okamoto Y, Yamamoto T, Kalaria RN, Senzaki H, Maki T, Hase Y, Kitamura A, Washida K, Yamada M, Ito $\mathrm{H}$, Tomimoto $\mathrm{H}$, Takahashi $\mathrm{R}$, Ihara $\mathrm{M}$ (2012) Cerebral hypoperfusion accelerates cerebral amyloid angiopathy and promotes cortical microinfarcts. Acta neuropathologica 123:381394.

Ophir G, Meilin S, Efrati M, Chapman J, Karussis D, Roses A, Michaelson DM (2003) Human apoE3 but not apoE4 rescues impaired astrocyte activation in apoE null mice. Neurobiol Dis 12:56-64.

Picklo MJ, Sr., Olson SJ, Hayes JD, Markesbery WR, Montine TJ (2001) Elevation of AKR7A2 (succinic semialdehyde reductase) in neurodegenerative disease. Brain Res 916:229-238.

Reddy PH, Mani G, Park BS, Jacques J, Murdoch G, Whetsell W, Jr., Kaye J, Manczak M (2005) Differential loss of synaptic proteins in Alzheimer's disease: implications for synaptic dysfunction. Journal of Alzheimer's disease : JAD 7:103-117; discussion 173-180.

Roberts RC, Roche JK, McCullumsmith RE (2014) Localization of excitatory amino acid transporters EAAT1 and EAAT2 in human postmortem cortex: a light and electron microscopic study. Neuroscience 277:522-540.

Rohe M, Carlo AS, Breyhan H, Sporbert A, Militz D, Schmidt V, Wozny C, Harmeier A, Erdmann B, Bales KR, Wolf S, Kempermann G, Paul SM, Schmitz D, Bayer TA, Willnow TE, Andersen OM (2008) Sortilin-related receptor with A-type repeats (SORLA) affects the amyloid precursor protein-dependent stimulation of ERK signaling and adult neurogenesis. The Journal of biological chemistry 283:14826-14834.

Rose EM, Koo JC, Antflick JE, Ahmed SM, Angers S, Hampson DR (2009) Glutamate transporter coupling to Na,K-ATPase. The Journal of neuroscience : the official journal of the Society for Neuroscience 29:8143-8155.

Roses AD, Saunders AM, Lutz MW, Zhang N, Hariri AR, Asin KE, Crenshaw DG, Budur K, Burns DK, Brannan SK (2014) New applications of disease genetics and pharmacogenetics to drug development. Curr Opin Pharmacol 14:81-89. 
Sato N, Morishita R (2013) Roles of vascular and metabolic components in cognitive dysfunction of Alzheimer disease: short- and long-term modification by non-genetic risk factors. Front Aging Neurosci 5:64.

Scimemi A (2014) Structure, function, and plasticity of GABA transporters. Front Cell Neurosci 8:161.

Shankar GM, Walsh DM (2009) Alzheimer's disease: synaptic dysfunction and Abeta. Mol Neurodegener 4:48.

Skoog I, Hesse C, Fredman P, Andreasson LA, Palmertz B, Blennow K (1997) Apolipoprotein E in cerebrospinal fluid in 85-year-old subjects. Relation to dementia, apolipoprotein $E$ polymorphism, cerebral atrophy, and white matter lesions. Arch Neurol 54:267-272.

Soria G, Tudela R, Marquez-Martin A, Camon L, Batalle D, Munoz-Moreno E, Eixarch E, Puig J, Pedraza S, Vila E, Prats-Galino A, Planas AM (2013) The ins and outs of the BCCAo model for chronic hypoperfusion: a multimodal and longitudinal MRI approach. PLoS One 8:e74631.

Sweatt AJ, Garcia-Espinosa MA, Wallin R, Hutson SM (2004) Branched-chain amino acids and neurotransmitter metabolism: expression of cytosolic branched-chain aminotransferase (BCATc) in the cerebellum and hippocampus. The Journal of comparative neurology 477:360370.

Tai LM, Ghura S, Koster KP, Liakaite V, Maienschein-Cline M, Kanabar P, Collins N, Ben-Aissa M, Lei AZ, Bahroos N, Green SJ, Hendrickson B, Van Eldik LJ, LaDu MJ (2015) APOE-modulated Abeta-induced neuroinflammation in Alzheimer's disease: current landscape, novel data, and future perspective. J Neurochem 133:465-488.

Tanaka S, Uehara T, Nomura Y (2000) Up-regulation of protein-disulfide isomerase in response to hypoxia/brain ischemia and its protective effect against apoptotic cell death. The Journal of biological chemistry 275:10388-10393.

Taniguchi M, Okayama Y, Hashimoto Y, Kitaura M, Jimbo D, Wakutani Y, Wada-Isoe K, Nakashima K, Akatsu H, Furukawa K, Arai H, Urakami K (2008) Sugar chains of cerebrospinal fluid transferrin as a new biological marker of Alzheimer's disease. Dement Geriatr Cogn Disord 26:117-122.

Tapiola T, Pennanen C, Tapiola M, Tervo S, Kivipelto M, Hanninen T, Pihlajamaki M, Laakso MP, Hallikainen M, Hamalainen A, Vanhanen M, Helkala EL, Vanninen R, Nissinen A, Rossi R, Frisoni GB, Soininen H (2008) MRI of hippocampus and entorhinal cortex in mild cognitive impairment: a follow-up study. Neurobiology of aging 29:31-38.

Valerio Romanini C, Dias Fiuza Ferreira E, Correia Bacarin C, Verussa MH, Weffort de Oliveira RM, Milani H (2013) Neurohistological and behavioral changes following the four-vessel occlusion/internal carotid artery model of chronic cerebral hypoperfusion: comparison between normotensive and spontaneously hypertensive rats. Behavioural brain research 252:214-221.

Verret L, Mann EO, Hang GB, Barth AM, Cobos I, Ho K, Devidze N, Masliah E, Kreitzer AC, Mody I, Mucke L, Palop JJ (2012) Inhibitory interneuron deficit links altered network activity and cognitive dysfunction in Alzheimer model. Cell 149:708-721.

Wallach G, Lallouette J, Herzog N, De Pitta M, Ben Jacob E, Berry H, Hanein Y (2014) Glutamate mediated astrocytic filtering of neuronal activity. PLoS Comput Biol 10:e1003964.

Wang X, Lin F, Gao Y, Lei H (2015) Bilateral common carotid artery occlusion induced brain lesions in rats: A longitudinal diffusion tensor imaging study. Magn Reson Imaging 33:551-558.

Wisniewski JR, Zougman A, Nagaraj N, Mann M (2009) Universal sample preparation method for proteome analysis. Nat Methods 6:359-362.

Xu PT, Li YJ, Qin XJ, Kroner C, Green-Odlum A, Xu H, Wang TY, Schmechel DE, Hulette CM, Ervin J, Hauser M, Haines J, Pericak-Vance MA, Gilbert JR (2007) A SAGE study of apolipoprotein $E 3 / 3, E 3 / 4$ and E4/4 allele-specific gene expression in hippocampus in Alzheimer disease. Mol Cell Neurosci 36:313-331. 
Yamazaki M, Matsuo R, Fukazawa Y, Ozawa F, Inokuchi K (2001) Regulated expression of an actinassociated protein, synaptopodin, during long-term potentiation. J Neurochem 79:192-199.

Zadori D, Datki Z, Penke B (2007) [The role of chronic brain hypoperfusion in the pathogenesis of Alzheimer's disease--facts and hypotheses]. Ideggyogyaszati szemle 60:428-437.

Zekonyte J, Sakai K, Nicoll JA, Weller RO, Carare RO (2016) Quantification of molecular interactions between ApoE, amyloid-beta (Abeta) and laminin: Relevance to accumulation of Abeta in Alzheimer's disease. Biochimica et biophysica acta 1862:1047-1053.

Zhiyou C, Yong Y, Shanquan S, Jun Z, Liangguo H, Ling Y, Jieying L (2009) Upregulation of BACE1 and beta-amyloid protein mediated by chronic cerebral hypoperfusion contributes to cognitive impairment and pathogenesis of Alzheimer's disease. Neurochem Res 34:1226-1235. 